\title{
WAT WIL HET ZEGGEN OM GEADVISEERD TE WORDEN?
}

\author{
door Dr.Ir.Th.P.Tromp
}

„I want to learn, but I don't like to be taught”.

\section{Van Probleem tot Opdracht}

Iedere ondernemer wordt min of meer regelmatig geconfronteerd met velerlei problemen, die op korte termijn om een oplossing vragen: snel stijgende omzetten, dalende rentabiliteit, groot verloop, afnemende barrières in E.E.G., voortdurende successen van concurrenten, vernieuwing van assortiment, overmatige $k$ waliteitsklachten, toenemend aantal orderannuleringen, stijgende kostprijzen, weerstand bij credietverstrekkers e.d.

Deze problemen zijn echter meestal slechts de aan de oppervlakte komende verschijnselen van veel dieperliggende vraagstukken van organisatorische of technische aard, die als zodanig nog niet zijn herkend.

Het is dan ook begrijpelijk dat als men het probleem voorlegt aan 10 verschillende, op hun gebied kundige mensen, men 10 verschillende formuleringen krijgt van hetzelfde probleem, al naar de aard en de deskundigheid van de gevraagde!

Om een dergelijk principieel vraagstuk aan te pakken is in de eerste plaats tijd en specialistische kennis nodig, maar daarnaast de mogelijkheid om afstand te nemen van de ontstane situatie. Dit noodt er als het ware toe een (organisatie-) adviseur in te schakelen.

De opdrachtgever zelf beschikt immers niet over de tijd en heeft onvoldoende kennis van en ervaring met de methodieken om deze - meestal incidenteel optredende - problemen op te lossen. Bovendien mag van een adviseur verwacht worden dat hij, niet belast met historisch gegroeide situaties, die weliswaar van groot belang zijn voor het nemen van juiste beslissingen, zich daarvan op verfrissende wijze kan distanciëren. Tenslotte wordt de adviseur niet gestoord door de zorgen van alledag en kan zich daarom ongehinderd met de problemen van de toekomst bezighouden waardoor opportunistische oplossingen worden vermeden en de implementatie goed kan worden voorbereid. Er zijn dus vele voordelen verbonden aan het inschakelen van adviseurs bij het oplossen van de dieper liggende organisatievraagstukken, toch kunnen de adviseurs ze niet oplossen.

Het raadplegen van een (organisatie-)adviseur vertoont overeenkomst met het consulteren van een arts. Zoals de arts slechts de juiste diagnose kan stellen als de patiënt niet alleen zijn klachten uit, maar ook zijn persoonlijke problemen prijsgeeft, zo kan de adviseur slechts van dienst zijn als de geadviseerde werkelijk geadviseerd wenst te worden! Men realisere zich dat - evenals bij de geneeskunde geneesmiddelen meestal onaangenaam smaken! Te veel komt het nog voor dat een advies gevraagd wordt voor een probleem waarvan de oplossing al bekend is maar onaangenaam om uit te voeren. De adviseur wordt dan gezien of als de boeman, die met een onplezierig advies komt, of als de tovenaar, die onverwachte mogelijkheden tevoorschijn tovert; maar niet als de helper bij de oplossing van het eigen probleem van de opdrachtgever. 


\section{De Opdracht}

Het werkelijke vraagstuk is niet zonder meer uit de verschijnselen, die wel veel aandacht opeisen, af te leiden.

Daarom is het veelal een goede start een adviseur een beperkt vooronderzoek te laten doen om de werkelijke problemen te indiceren en aanwijzingen te geven voor een in te stellen intensief onderzoek. Op grond van deze voorstudie kan dan een opdracht worden geformuleerd en begrensd en de meest deskundige adviseur worden gekozen. Bij definitief formuleren moet men zich goed bewust zijn van kosten en duur van het onderzoek. Gerekend toch mag worden dat tegenover één uur van de adviseur 3 tot 5 uur van medewerkers van het bedrijf staan! In verband hiermee kan het soms bepaald gewenst zijn, deelopdrachten te verstrekken, die echter wel moeten passen in eventuele latere volledige behandeling van het vraagstuk.

In het samenspel van adviseur en geadviseerde is de keuze van de adviseur - de geadviseerde is immers een ,gegeven" - van beslissende betekenis. Wat management-opvatting betreft moet hij bij de opdrachtgever passen en ook qua karakter behoren ze elkaar te "liggen”. Dit alles geldt vooral naarmate de te onderzoeken vraagstukken van meer organisatorische dan technische aard zijn. De adviseur van het vooronderzoek en de uiteindelijke adviseur behoeven dan ook bepaaldelijk niet dezelfde te zijn.

De opdracht is echter dan pas voldoende geregeld als opdrachtgever en adviseur zich hebben gerealiseerd hoe het onderzoek bij de medewerkers van de desbetreffende onderneming moet worden geïntroduceerd. Niet alleen zal de adviseur afhankelijk zijn van deze medewerkers bij het verzamelen en ordenen van zijn informatie, maar ook zullen zij het zijn die naderhand het voorgestelde advies zullen moeten waarmaken.

Vóór de opdrachtgever de opdracht definitief verstrekt, dient hij zich wel af te vragen of hij er zelf voldoende tijd aan kan besteden. Met het geven van de opdracht is hij niet van het probleem af. Daarom behoort nooit een nieuwe opdracht te worden aangepakt alvorens de voorgaande is afgewerkt, conclusies zijn getrokken en de noodzakelijke maatregelen zijn genomen.

\section{Uitvoering van de Opdracht}

Bij de uitvoering van de opdracht zal de opdrachtgever zelf ook voortdurend betrokken moeten worden wil het uiteindelijke resultaat zijn goedkeuring en steun kunnen verkrijgen.

Vanzelfsprekend is de intensiteit van het samenspel tussen opdrachtgever en adviseur afhankelijk van de desbetreffende vraagstukken.

Naarmate het probleem meer technisch is en minder in de organisatie ingrijpt kunnen de functionele eisen en doelstellingen duidelijker in de opdracht worden vastgelegd, kan meer aan de deskundigheid van de adviseur worden overgelaten en kan het contact wonden beperkt. Toch zal ook dan de voorgestelde oplossing steeds moeten worden getoetst aan de eigen aard van het bedrijf.

Hiervan uitgaande zal het duidelijk zijn dat het noodzakelijke contact tussen opdrachtgever en adviseur zal moeten toenemen bij de onderstaande, in volgorde geplaatste opdrachten ten aanzien van: 
a. ontwerp van een gebouw

b. verbetering of vernieuwing van een transportsysteem of werkmethode resp. procédé.

c. scholing en opleiding van medewerkers; werkstructurering.

d. produktiebesturing en automatische informatieverwerking.

e. (re-)organisatie van de onderneming of gedeelten ervan.

In de hierbeschreven volgorde neemt de „exclusieve deskundigheid” af en de invloed van het ,gezonde verstand" toe. Maar wat belangrijker is, in de gegeven volgorde wordt de invloed van de stijl van leidinggeven op en daarmee de persoonlijke betrokkenheid van de opdrachtgever bij de oplossing van het probleem steeds groter. Veel adviezen hebben een ontijdig einde gevonden in bureauladen omdat men hiermede geen rekening heeft gehouden! Toch realiseren opdrachtgevers dit zichzelf ook niet steeds. Veelal tonen zij meer interesse in ontwerp en uitvoering van een kantoor- of fabrieksgebouw dan eigenlijk noodzakelijk is. Mogelijk dat status en image van de onderneming of ook concreetheid van het probleem hierbij een rol spelen.

Hiertegenover blijkt het soms moeilijk de opdrachtgever te bepalen bij de problemen die samenhangen met zijn persoonlijke stijl van leidinggeven, zoals die voorkomen bij management-development- en reorganisatie-opdrachten.

Het intensieve contact met de adviseur waartoe de opdrachtgever zich moet dwingen houdt nauw verband met het verstrekken van de historische achtergrond en al díe basisgegevens over de onderneming en haar philisophy waarop de adviseur zijn advies moet kunnen bouwen. Om de tijd die de opdrachtgever aan het onderwerp moet geven zoveel mogelijk te beperken én om de continuïteit zo goed mogelijk te verzorgen is het bij externe adviseurs gewenst aan hem gedurende het gehele onderzoek een partner uit het bedrijf toe te voegen die de bedrijfskennis inbrengt en die het volledige vertrouwen van de opdrachtgever geniet. Een medewerker van zodanig niveau dat hij druk kan zetten achter de onderzoekingen in het bedrijf en van de adviseur, maar die ook in staat is later de ontwikkelde gedachtengang uit te dragen en die kan bijdragen in de realisatie van het advies.

Bij een bouwwerk, waar het functionele onderzoek vaak in het bedrijf zelf reeds heeft plaatsgehad, is de noodzaak van zo'n partner misschien wat minder dan bij management-development- of reorganisatie-opdrachten, waar van een extern adviseur zonder een dergelijke medewerker nauwelijks een aanvaardbaar advies kan worden verwacht. Juist in deze laatste opdrachten moet worden voorkomen dat de adviseur al het denkwerk alleen doet en zodoende met een management-development-programma of organisatievoorstel komt wat hij rationeel geaccepteerd kan krijgen, waar hij opdrachtgever en naaste medewerkers wel van overtuigt, maar waartoe hij ze niet weet te bekeren! Deze opdrachten zijn alle zo emotioneel geladen dat rationeel overtuigen niet voldoende is.

Belangrijk is het dan ook voor de adviseur niet a tort et à travers zijn eigen opvattingen te willen pousseren maar open te staan voor de ideeën van hen die in het bedrijf werkzaam zijn en die soms uitstekende suggesties hebben maar deze niet door kunnen zetten of wier stem niet gehoord wordt. Door wat in vele delen van het bedrijf leeft zinvol bij elkaar te brengen, dit te complementeren met eigen "vakmanschap" en dan goed te formuleren kan men soms ontstellend veel berei- 
ken. Hierbij geldt: het opdienen van het menu is minstens even belangrijk of nòg belangrijker dan de samenstelling ervan of het bereiden van de gerechten.

Het is in ieder geval duidelijk dat het contact tussen opdrachtgever en adviseur niet kan wachten tot het uitbrengen van het advies (rapport). De opdrachtgever moet zich tijdig inleven in de ontwikkeling van zijn probleem en in de gedachtengang van zijn adviseur.

\section{Het Rapport}

Uit de grote nadruk die tot nu toe gelegd is op het contact: opdrachtgever, bedrijf en adviseur kan reeds worden afgeleid dat slechts relatieve betekenis gehecht kan worden aan het uiteindelijke advies (rapport). Het uiteindelijke definitieve advies is door de vele intensieve en persoonlijke contacten mentaal reeds zo voorbereid dat acceptatie nog nauwelijks nodig is.

In een eindrapport of advies liggen grote gevaren. Het zal de adviseur vrijwel onmogelijk zijn het bedrijf in de korte tijd van onderzoek zo goed te leren kennen dat het rapport geen onjuistheden bevat (hopelijk van onbelangrijke aard!). De opdrachtgever zal er zorg voor moeten dragen dat het rapport positief benaderd wordt en dat is eenvoudiger naarmate het in nauwer contact met het bedrijf is tot stand gekomen.

Een advies of rapport houdt altijd critiek in, die moeilijker te verteren is naarmate het minder materiële zaken raakt.

In het stadium van het rapport wordt dan ook de meeste tact vereist van opdrachtgever en adviseur. Het gaat immers niet om het gelijk hebben, maar belangrijker is het gelijk krijgen of wel het op gelijke ,noemer" krijgen van alle betrokkenen. Dit is gemakkelijker als men er van uit gaat dat er niet een ,enig goede" oplossing bestaat, maar dat een gerealiseerde goede "tweede" mogelijkheid altijd beter is dan een niet geaccepteerde perfecte (maar wat is dat dan?) oplossing.

Wat de opvatting ook is van de adviseur, voor de opdrachtgever is in ieder geval de opdracht niet geëindigd met het rapport. Hij is in wezen niet geïnteresseerd in een advies of rapport maar in bereikte resultaten.

\section{De Realisatie}

Een aantal adviseurs, waaronder met wereldreputatie, meent dat hun taak met het uitbrengen van het advies beëindigd is en de realisatie geheel aan de opdrachtgever en zijn medewerkers moet worden overgelaten.

Natuurlijk kan de adviseur geen verantwoordelijkheid op zich nemen voor het verwezenlijken van het advies, maar de ervaring leert dat geen enkel advies rekening kan houden met alle omstandigheden en details. En het zijn juist deze details en onverwacht wijzigende situaties die gemakkelijk ontsporingen kunnen veroorzaken en de betrokkenen terug doen vallen in hun oude gewoonten en oorspronkelijke organisatorische verhoudingen. Een organisatie wordt nict veranderd door een nieuw organisatieschema op te stellen of de functies en procedures opnieuw vast te stellen en te beschrijven. Een re-organisatie van enige omvang betekent een mentaliteitsverandering. Organiseren is een mentaal en dynamisch proces, waarbij het advies een doelbepaling en wegwijzer kan zijn.

Is een advies of rapport eenmaal aanvaard dan is de daaruitsprekende gedach- 
tengang of philosophy het belangrijkste en deze zal gedurende het realisatieproces moeten worden vastgehouden.

Tijdens de implementatie zal men steeds op interpretatiemoeilijkheden stuiten en daarbij is de adviseur onmisbaar. $\mathrm{Hij}_{\mathrm{ij}}$ zal voortdurend behulpzaam moeten zijn om binnen de geest van het advies de optredende detailmoeilijkhden op te lossen. De reeds tijdens de analyse en voorbereiding bestaande driehoeksverhouding: Opdrachtgever, Bedrijf en (Organisatie-) Adviseur behoudt haar waarde gedurende de realisatie.

Door het bewaken van de geaccepteerde gedachtengang en visie treedt de adviseur tijdens deze periode op als opleider en opvoeder en is zijn taak in de eerste plaats: Management-Development. Dit geldt niet alleen voor de medewerkers van de opdrachtgever, maar ook voor de opdrachtgever zelf. Deze toch is meestal zo bezet met allerlei zaken die een snelle beslissing vragen, dat hij zich niet steeds realiseert dat de reorganisatie ook zijn activiteiten raakt. Voor hem is de adviseur de spiegel waarin hij regelmatig wordt gedwongen te kijken. Als men op deze wijze wil samenwerken met een adviseur dan is het duidelijk wat reeds eerder gezegd werd over het belang van de keuze van de adviseur.

Eigenlijk is het toch zo dat de realisatie al begint tijdens analyse en de voorbereiding. Reeds dan gaat van de wijze van denken en werken van de adviseur grote invloed uit op opdrachtgever en bedrijf. Te meer reden om bij de keuze van zijn adviseur omzichtig te werk te gaan en opdringerige bureaus, die snelle resultaten beloven, zeer critisch te beschouwen.

Wat wil het zeggen geadviseerd te worden?

Het betekent open staan voor de mening van een ander, die bewezen heeft te kunnen luisteren, situaties te kunnen evalueren en een aangepast advies te kunnen geven. Het betekent ook critiek willen aanvaarden en hiervan willen leren. En tenslotte: samen met die ander en de betrokkenen in het bedrijf een passende oplossing willen zoeken voor bedrijfsproblemen die soms anders blijken te zijn dan men op het eerste gezicht heeft gedacht. 